\title{
Long-term data on sirolimus treatment in patients with lupus nephritis
}

\author{
Desmond Y.H. YAP ${ }^{1}$, Colin Tang ${ }^{1}$, Gary C.W. Chan ${ }^{1}$, Lorraine P.Y. Kwan ${ }^{1}$, Maggie \\ K.M. Ma ${ }^{1}$, Maggie M.Y. Mok ${ }^{1}$ and Tak Mao Chan ${ }^{1}$ \\ ${ }^{1}$ Division of Nephrology, Department of Medicine, Queen Mary Hospital, The University of Hong Kong, Hong Kong \\ Correspondence to: Tak Mao Chan, email: dtmchan@hku.hk
}

Keywords: sirolimus; mTOR; malignancy; lupus nephritis; long-term

Received: October 11, $2017 \quad$ Accepted: December 05, 2017

Published: January 12, 2018

Copyright: YAP et al. This is an open-access article distributed under the terms of the Creative Commons Attribution License 3.0 (CC BY 3.0), which permits unrestricted use, distribution, and reproduction in any medium, provided the original author and source are credited.

\section{ABSTRACT}

Our pilot short-term data suggested efficacy of sirolimus treatment in lupus nephritis (LN) patients, but its long-term data remains limited. We retrospectively reviewed 16 Class III/IV/V LN patients who have received prednisolone and sirolimus either as initial or maintenance treatment. Sixteen patients received sirolimus treatment ( 9 due to intolerance to standard immunosuppressants and 7 due to a history of malignancy) for $\mathbf{4 5 . 3} \pm \mathbf{3 6 . 5}$ months. In five patients sirolimus and prednisolone was given as induction for active nephritis, and they showed improvements in proteinuria ( $2.8 \pm 1.9 \mathrm{~g} /$ day at baseline, $0.1 \pm 0.1 \mathrm{~g} /$ day after 36 months, $p=0.011)$, anti-dsDNA (107.7 $\pm 91.9 \mathrm{IU} / \mathrm{mL}$ and $37.0 \pm 55.4 \mathrm{IU} / \mathrm{mL}$ respectively, $p=0.178)$ and $C_{3}(54.8 \pm 26.1 \mathrm{mg} / \mathrm{dL}$ and $86.3 \pm 18.6 \mathrm{mg} / \mathrm{dL}$ respectively, $p=0.081)$. Eleven patients received sirolimus and low-dose prednisolone as long-term maintenance, and they showed continued improvement in $C 3(90.4 \pm 18.1 \mathrm{mg} / \mathrm{dL}$ and $117.7 \pm 25.1$ $\mathrm{mg} / \mathrm{dL}$ at commencement and after 36 months respectively, $p=0.025$ ) and stable renal function (eGFR $58.6 \pm 25.8 \mathrm{ml} / \mathrm{min}$ and $63.0 \pm 29.6 \mathrm{~mL} / \mathrm{min}$ respectively, $p$ $=0.239)$ and proteinuria $(0.8 \pm 0.7 \mathrm{~g} /$ day and $0.7 \pm 0.7 \mathrm{~g} /$ day respectively, $p=$ 0.252). Renal flare occurred in one patient and another patient with Stage 4 chronic kidney disease when sirolimus was started developed endstage renal failure after 27 months. Sirolimus was discontinued in five patients, in four cases related to drug sideeffects. Deterioration of dyslipidaemia occurred in four patients, but was adequately controlled with statin therapy. The preliminary evidence suggests that sirolimus may serve as an alternative treatment for $\mathrm{LN}$ who do not tolerate standard treatment or had history of malignancy, and with acceptable long-term safety profile.

\section{INTRODUCTION}

Lupus nephritis (LN) is a serious organ involvement in patients with systemic lupus erythematosus (SLE), and is associated with excessive patient mortality [1, 2]. LN can occur in approximately $50 \%$ of Caucasian SLE patients, and up to $60-70 \%$ in Asian SLE patients [1-3]. The disease course of $\mathrm{LN}$ is characterized by episodes of active renal flares intercalated with periods of disease quiescence. The disease state is usually determined by renal (e.g. proteinuria, eGFR, serum creatinine) and lupus serological parameters (e.g. antidsDNA and C3 levels). Active LN usually presents with nephrotic-range proteinuria and with or without active urine sediments and renal dysfunction, and is often accompanied by active lupus serology. Disease quiescence is denoted by low-grade/absence of proteinuria and inactive urinary sediments, and is often associated with quiescent serological markers. The current standardof-care induction treatments for active severe $\mathrm{LN}$ are corticosteroids combined with either cyclophosphamide (CYC) or mycophenolate mofetil (MMF), followed by low-dose corticosteroids plus either MMF or azathioprine (AZA) maintenance to prevent relapse [4-8]. While these immunosuppressive regimens have established short- and long-term efficacy for the treatment of LN, each agent is associated with its potential toxicities and thus there is always a keen demand for novel therapeutic agents to 
facilitate tailoring treatment according to the distinct needs of individual patients [9-12].

Sirolimus is mammalian target of rapamycin (mTOR) inhibitor and has pleotropic actions which include immunosuppressive, anti-proliferative and anti-fibrotic effects [13]. The current clinical uses of mTOR inhibitors include the prevention of organ transplantation rejection and treatment of advanced neoplasms [13-15]. By virtue of its immunosuppressive mechanisms, it is speculated that sirolimus can also serve as a potential therapy for LN. In this context, previous animal studies from our group and other investigators have demonstrated that sirolimus could delay the onset of renal manifestations and could also ameliorate established nephritis in $N Z B / W F 1$ mice [16-19]. Early studies have reported that sirolimus could improve disease activity scores in 9 active SLE patients (2 with renal involvement) who were refractory to standard immunosuppressive treatments [20]. We have also reported pilot short-term data on mTOR inhibitors in the treatment of LN patients [21]. However, this series involved only seven patients with treatment duration of 17 to 37 months. We hereby report a retrospective study on the efficacy and safety of mTOR inhibitor treatment in 16 LN patients who received this treatment for approximately four years.

\section{RESULTS}

\section{Sirolimus dose and trough level}

$16 \mathrm{LN}$ patients were included (5 started on sirolimus during active LN and 11 during disease quiescence) (Tables 1 and 2) The duration of sirolimus treatment was $45.3 \pm 36.5$ months. Nine patients received sirolimus because of intolerance to standard immunosuppressants ( 6 related to MMF and 3 related to $\mathrm{CNI}$ intolerance) and seven patients due to a history of malignancy (two had renal cell carcinoma, two had breast cancer, one had salivary gland carcinoma, one had ovarian cancer and one had vulval carcinoma). For patients who received prednisolone and sirolimus as continuous inductionmaintenance treatment, the actual dose at $6,12,24$ and 36 months was $2.0 \pm 1.0 \mathrm{mg} / \mathrm{D}, 1.8 \pm 1.3 \mathrm{mg} / \mathrm{D}$, $1.8 \pm 1.3 \mathrm{mg} / \mathrm{D}$ and $1.8 \pm 0.8 \mathrm{mg} / \mathrm{D}$ respectively. The corresponding 12-hr trough sirolimus levels were $6.7 \pm$ $0.9 \mu \mathrm{g} / \mathrm{L}, 4.4 \pm 1.7 \mu \mathrm{g} / \mathrm{L}, 4.2 \pm 1.6 \mu \mathrm{g} / \mathrm{L}$ and $4.2 \pm 0.6$ $\mu \mathrm{g} / \mathrm{L}$ respectively. Two patients who received sirolimus induction also received concomitant diltiazem treatment but their sirolimus was discontinued at $5.0 \pm 1.4$ months (the sirolimus dosage was $2.0 \pm 0.0 \mathrm{mg} /$ day at the time of sirolimus discontinuation, and the corresponding 12-hr trough levels were $7.7 \mu \mathrm{g} / \mathrm{L}$ and $2.9 \mu \mathrm{g} / \mathrm{L}$ respectively). For patients who were initiated on sirolimus during disease quiescence, the actual dose was $1.3 \pm 0.5 \mathrm{mg} / \mathrm{D}, 1.2 \pm 0.5$ $\mathrm{mg} / \mathrm{D}, 1.3 \pm 0.6 \mathrm{mg} / \mathrm{D}$ and $1.3 \pm 0.5 \mathrm{mg} / \mathrm{D}$ after $6,12,24$ and 36 months respectively, and the corresponding 12-hr trough levels were $4.5 \pm 1.4 \mu \mathrm{g} / \mathrm{L}, 4.0 \pm 1.7 \mu \mathrm{g} / \mathrm{L}, 4.0 \pm$ $1.2 \mu \mathrm{g} / \mathrm{L}$ and $3.9 \pm 0.9 \mu \mathrm{g} / \mathrm{L}$ respectively. Two patients who were treated with sirolimus during maintenance phase also received concomitant diltiazem.

\section{Renal outcomes}

Treatment of active $\mathrm{LN}$ with prednisolone and sirolimus was associated with progressive reduction of proteinuria over time $(2.8 \pm 1.9 \mathrm{~g} /$ day, $2.1 \pm 1.4 \mathrm{~g} /$ day, $0.5 \pm 0.3 \mathrm{~g} /$ day, $0.2 \pm 0.1 \mathrm{~g} /$ day and $0.1 \pm 0.1 \mathrm{~g} /$ day at baseline and after $6,12,24$ and 36 months of treatment; $p$ $=0.064,0.063,0.063$ and 0.010 compared with baseline respectively) (Figure 1A). Improvement in eGFR was also observed $\left(58.8 \pm 29.1 \mathrm{ml} / \mathrm{min} / 1.73 \mathrm{~m}^{2}, 75.3 \pm 14.0\right.$ $\mathrm{ml} / \mathrm{min} / 1.73 \mathrm{~m}^{2}, 87.3 \pm 4.5 \mathrm{ml} / \mathrm{min} / 1.73 \mathrm{~m}^{2}, 73.7 \pm 14.6 \mathrm{ml} /$ $\mathrm{min} / 1.73 \mathrm{~m}^{2}$ and $79.0 \pm 9.8 \mathrm{ml} / \mathrm{min} / 1.73 \mathrm{~m}^{2}$ at baseline and after 6, 12, 24 and 36 months of treatment; $p=0.013$, $0.066,0.039,0.078$ compared with baseline respectively). (Figure 1A, 1B).

In patients who were treated with sirolimus during disease quiescence, proteinuria remained at a low level and there was no significant change over time $(0.8 \pm 0.7$ $\mathrm{g} /$ day, $0.2 \pm 0.2 \mathrm{~g} /$ day, $0.1 \pm 0.1 \mathrm{~g} /$ day, $0.3 \pm 0.2 \mathrm{~g} /$ day and $0.7 \pm 0.7 \mathrm{~g} /$ day at commencement of sirolimus and after $6,12,24$ and 36 months of treatment; $p=0.316,0.328$ and 0.252 compared with baseline respectively) (Figure 2, 2A). eGFR also remained stable after sirolimus treatment $\left(58.6 \pm 25.8 \mathrm{ml} / \mathrm{min} / 1.73 \mathrm{~m}^{2}, 64.0 \pm 28.9 \mathrm{ml} / \mathrm{min} / 1.73 \mathrm{~m}^{2}\right.$, $60.7 \pm 30.0 \mathrm{ml} / \mathrm{min} / 1.73 \mathrm{~m}^{2}, 65.0 \pm 28.8 \mathrm{ml} / \mathrm{min} / 1.73 \mathrm{~m}^{2}$ and $63.0 \pm 29.6 \mathrm{ml} / \mathrm{min} / 1.73 \mathrm{~m}^{2}$ at commencement of sirolimus and after $6,12,24$ and 36 months of treatment; $p=0.618$, 0.071 and 0.239 compared with baseline respectively) (Figure 2A, 2B). One patient developed end stage renal failure during follow-up. She had a serum creatinine level of $244 \mu \mathrm{mol} / \mathrm{L}\left(\mathrm{eGFR} 18 \mathrm{ml} / \mathrm{min} / 1.73 \mathrm{~m}^{2}\right.$ ) when started on sirolimus, and required dialysis 27 months later.

\section{Serological parameters and disease flare}

In patients with active $\mathrm{LN}$ who were treated with prednisolone and sirolimus their C3 level increased over time $(54.8 \pm 26.1 \mathrm{mg} / \mathrm{dL}, 93.7 \pm 34.3 \mathrm{mg} / \mathrm{dL}, 80.0 \pm 19.7$ $\mathrm{mg} / \mathrm{dL}, 84.7 \pm 17.4 \mathrm{mg} / \mathrm{dL}$ and $86.3 \pm 18.6 \mathrm{mg} / \mathrm{dL}$ at baseline and after $6,12,24$ and 36 months of treatment; $\mathrm{p}=0.148,0.100,0.077$ and 0.081 compared with baseline respectively) (Figure 1C), and anti-dsDNA level decreased over time $(107.7 \pm 91.9 \mathrm{IU} / \mathrm{mL}, 39.0 \pm 58.9 \mathrm{IU} / \mathrm{mL}, 20.7$ $\pm 27.1 \mathrm{IU} / \mathrm{mL}, 25.3 \pm 35.2 \mathrm{IU} / \mathrm{mL}$ and $37.0 \pm 55.4 \mathrm{IU} / \mathrm{mL}$ at baseline and after $6,12,24$ and 36 months respectively; $p=0.184,0.146,0.152$ and 0.178 compared with baseline respectively) (Figure 1C, 1D), though the differences did not reach statistical significance due to the marked individual variations.

In patients who were treated with sirolimus during disease quiescence, there was a significant increase in 
serum C3 levels after 6 months of treatment which was sustained over 36 months $(90.4 \pm 18.1 \mathrm{mg} / \mathrm{dL}, 110.0 \pm 23.6$ $\mathrm{mg} / \mathrm{dL}, 110.6 \pm 26.9 \mathrm{mg} / \mathrm{dL}, 109.7 \pm 22.9 \mathrm{mg} / \mathrm{dL}$ and 117.7 $\pm 25.1 \mathrm{mg} / \mathrm{dL}$ at commencement of sirolimus and after 6 , 12,24 and 36 months respectively; $p=0.018,0.009,0.001$ and 0.025 compared with baseline respectively) (Figure 2C). Anti-dsDNA titre was significantly lower after 6 months and remained low afterwards $(40.4 \pm 47.4 \mathrm{IU} / \mathrm{mL}$, $34.7 \pm 34.7 \mathrm{IU} / \mathrm{mL}, 31.5 \pm 28.7 \mathrm{IU} / \mathrm{mL}, 29.4 \pm 30.0 \mathrm{IU} / \mathrm{mL}$ and $10.4 \pm 10.9 \mathrm{IU} / \mathrm{mL}$ at baseline and after $6,12,24$ and 36 months respectively; $p=0.031,0.086,0.071$ and 0.324 compared with baseline) (Figure 2D, 2D). One patient had renal relapse, which occurred at 36 months after treatment. The dose of prednisolone was $9 \mathrm{mg}$ /day and the 12-hr trough sirolimus level was $2.6 \mu \mathrm{g} / \mathrm{L}$ when renal relapse occurred. One patient developed hematological flare (thrombocytopenia) while receiving prednisolone at 12.5 $\mathrm{mg}$ /day with 12-hr trough sirolimus level at $2.9 \mu \mathrm{g} / \mathrm{L}$, and responded to increased dose of prednisolone.
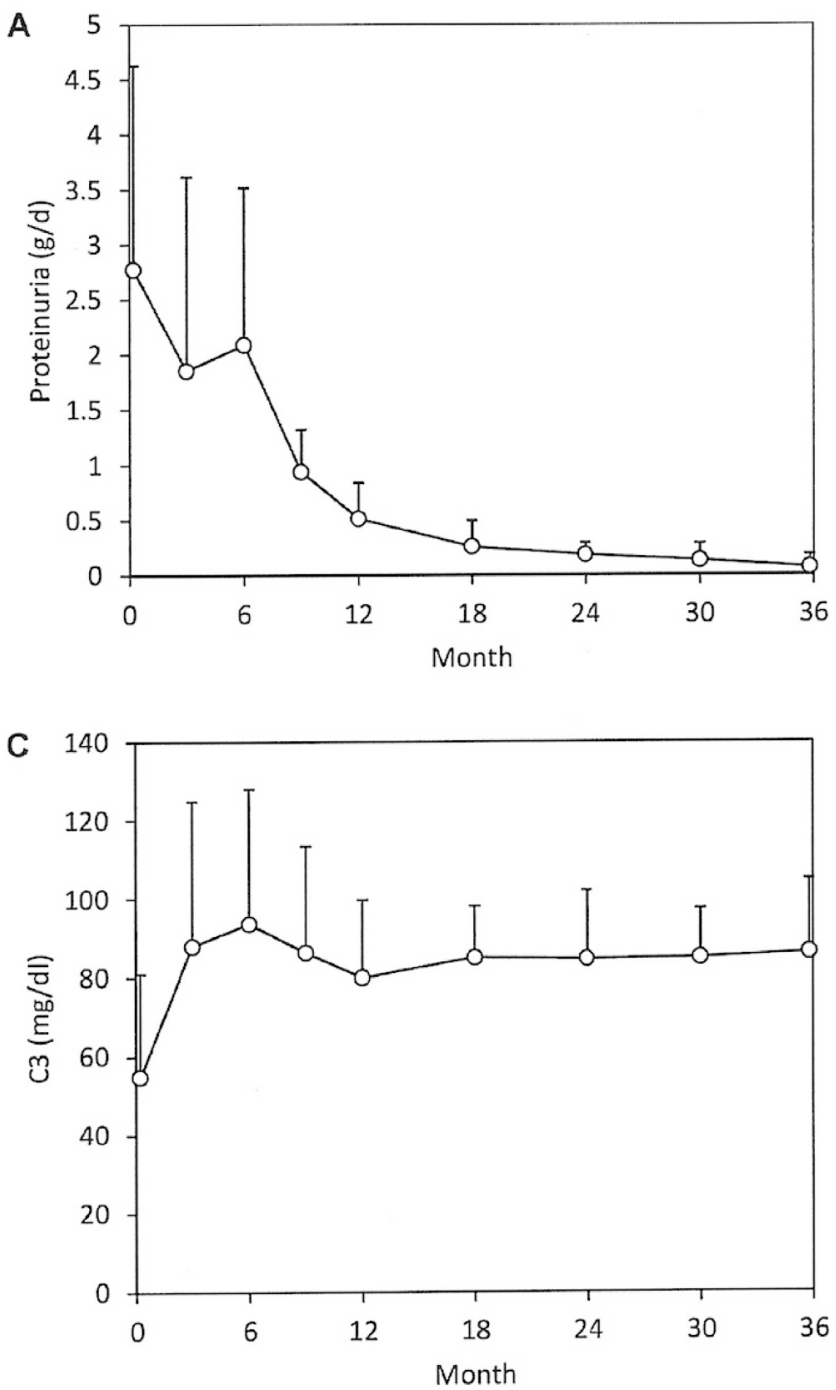

\section{Adverse events}

The adverse events experienced by LN patients who had received prednisolone and sirolimus treatment were summarized (Table 3). Sirolimus was discontinued in five patients after $2.6 \pm 0.8$ months of treatment. Drug discontinuation was due to skin rash in two patients, leucopenia in one patient, headache in one patient, and the occurrence of acute cholecystitis in one patient. Worsening of lipid profile occurred in four patients, but all were adequately controlled with statins. The LDL/ triglyceride levels were $2.8 \pm 0.8 / 1.4 \pm 0.9 \mathrm{mmol} / \mathrm{L}, 2.6 \pm$ $0.3 / 1.2 \pm 0.5 \mathrm{mmol} / \mathrm{L}, 3.0 \pm 0.4 / 1.3 \pm 0.6 \mathrm{mmol} / \mathrm{L}, 2.7 \pm$ $0.7 / 1.0 \pm 0.26 \mathrm{mmol} / \mathrm{L}$ and $2.4 \pm 0.7 / 0.9 \pm 0.2 \mathrm{mmol} / \mathrm{L}$ at baseline and after $6,12,24$ and 36 months respectively ( $p$ $=0.346 / 0.313,0.651 / 0.175,0.465 / 0.314$ and $0.896 / 0.427$ compared with baseline respectively). Three patients had infections (one with acute cholecystitis, one with herpes zoster and one with urinary tract infection) during follow-
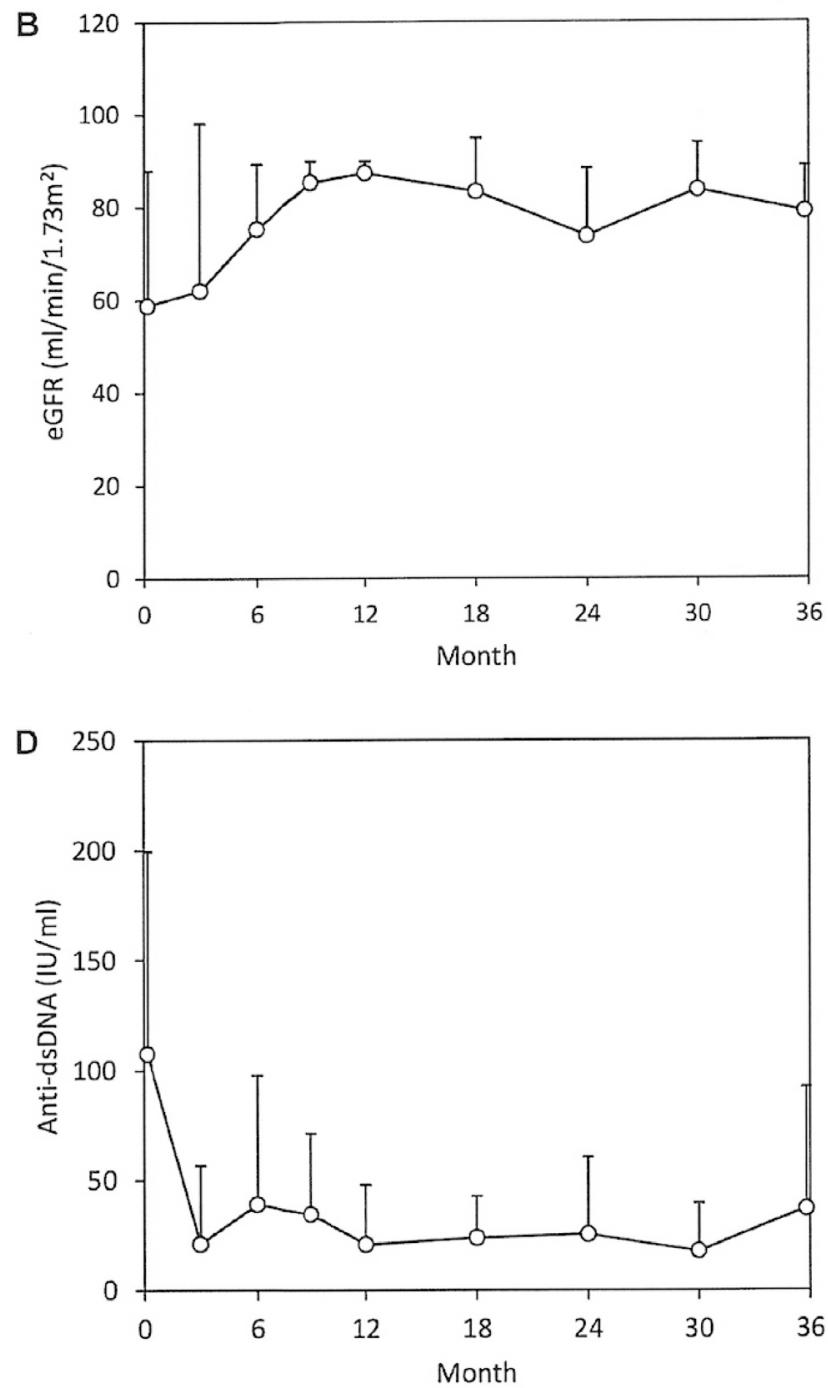

Figure 1: Longitudinal changes in (A) proteinuria (B) estimated GFR (C) serum C3 level and (D) anti-DNA level in 5 patients who receive prednisolone and sirolimus as initial therapy for active lupus nephritis. 
up and all responded to treatment. Leucopenia occurred in two patients (corresponding 12-hr trough levels were $3.2 \mu \mathrm{g} / \mathrm{L}$ and $7.6 \mu \mathrm{g} / \mathrm{L}$ respectively) and were not associated with infective complications. The white cell count normalized spontaneously in the first patient and after discontinuation of sirolimus in the second patient. The patient with acute cholecystitis also developed pancytopenia (corresponding 12-hr trough level was 7.7 $\mu \mathrm{g} / \mathrm{L}$ ), and the blood counts recovered after stopping sirolimus and treatment of infection.

\section{DISCUSSION}

Our data suggested that sirolimus could serve as an alternative treatment for LN patients who could not tolerate standard immunosuppressants or had a history of malignancy. The preliminary data suggests efficacy when given together with corticosteroid and side-effects did not appear excessive. mTOR inhibitors have the advantage of being non-nephrotoxic, except when given together with
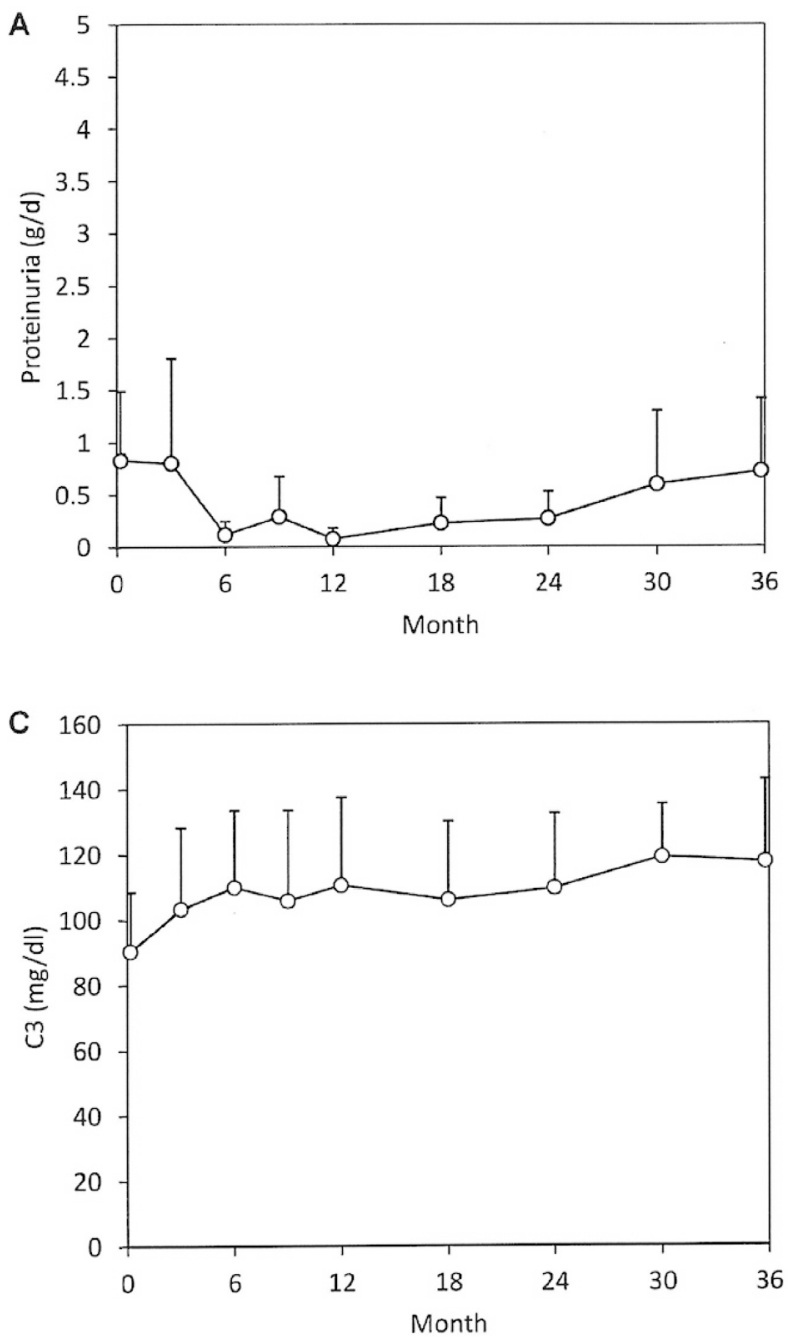

calcineurin inhibitors when they could increase the risk of nephrotoxicity due to the latter [22]. However, data from kidney transplant recipients suggested that mTOR inhibitors might induce proteinuria due to their action on glomerular podocytes and renal tubular cells, and significant increase in proteinuria after mTOR inhibitor treatment was associated with inferior renal allograft outcome [23-26]. Our data shows that in patients given prednisolone and sirolimus for the treatment of active LN, their proteinuria decreased while renal function improved. In patients who received low-dose prednisolone and sirolimus as long-term maintenance immunosuppression, proteinuria remained low and there was no significant change over time. These results do not suggest a significant risk of sirolimus in inducing or aggravating proteinuria with prolonged treatment lasting $45.3 \pm 36.5$ months. The progression to end stage renal failure after 27 months in one patient was attributed to underlying chronic renal damage, rather than the untoward effect of treatment.
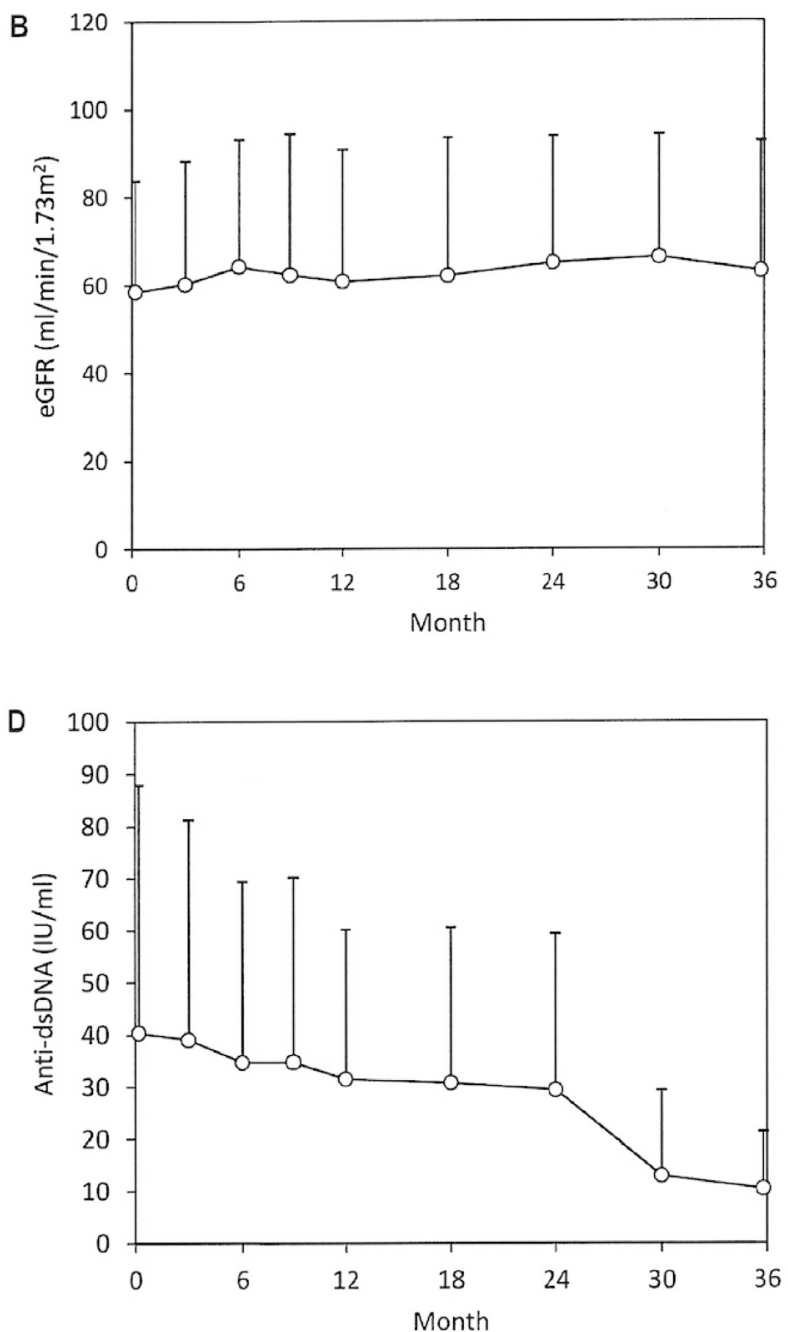

Figure 2: Longitudinal changes in (A) proteinuria (B) estimated GFR (C) serum C3 level and (D) anti-DNA level in 11 patients who receive prednisolone and sirolimus as maintenance immunosuppression during quiescent disease. 
Table 1: Clinical characteristics of 16 lupus nephritis patients who had received prednisolone and sirolimus treatment

Age (years)

$\operatorname{Sex}(\mathbf{F} / \mathrm{M})$

Duration of SLE before sirolimus treatment (months)

Class of LN

Class III \pm V or Class IV \pm V

Class V

Immunosuppressive regimen prior to sirolimus treatment

PRED + MMF

PRED + AZA

PRED + CNI

PRED alone

None

\section{Indications for sirolimus treatment}

Malignancy

Intolerance to MMF

Intolerance to $\mathrm{CNI}$

Clinical parameters before initiation of sirolimus treatment

Systolic blood pressure $(\mathrm{mmHg})$

Diastolic blood pressure ( $\mathrm{mmHg}$ )

eGFR $\left(\mathrm{ml} / \mathrm{min} / 1.73 \mathrm{~m}^{2}\right)$

Urine protein excretion (g/day)

Anti-dsDNA (IU/ml)

Serum C3 (mg/dl)

Fasting glucose $(\mathrm{mmol} / \mathrm{L})$

Total cholesterol $(\mathrm{mmol} / \mathrm{L})$

LDL cholesterol (mmol/L)

Triglyceride $(\mathrm{mmol} / \mathrm{L})$
$49.0 \pm 7.8$

$15: 1$

$204.6 \pm 113.7$

14

2

4

4

3

4

1

7

6

3

$114.2 \pm 15.1$

$70.8 \pm 10.6$

$58.6 \pm 25.8$

$1.8 \pm 1.7$

$65.6 \pm 72.8$

$77.1 \pm 27.2$

$4.5 \pm 0.4$

$5.1 \pm 0.8$

$2.8 \pm 0.8$

$1.4 \pm 0.9$

$\overline{\mathrm{AZA}}=$ azathioprine; $\mathrm{CNI}=$ calcineurin inhibitors; $\mathrm{LN}=$ lupus nephritis; $\mathrm{MMF}=$ mycophenolate mofetil; $\mathrm{PRED}=$ prednisolone

We also observed relatively favorable longterm disease stability in patients receiving low-dose prednisolone and sirolimus maintenance. Renal relapse occurred in only one patient and immune thrombocytopenia occurred in another patient, and both episodes were associated with low 12-hr trough sirolimus level. The potential contribution of sirolimus on long-term disease stability was also corroborated by the improvement in serological parameters after the initiation of sirolimus. The immunological effects of sirolimus on disease mechanisms in LN require further investigation. Possible mechanisms leading to a reduction of disease activity include reduction of intra-renal lymphoproliferation and MCP-1 expression, suppression of anti-dsDNA production and immune deposition, reversal of senescent phenotype of bone marrow-derived mesenchymal cells, promotion of Treg expansion and blockade of Th17 expansion[16-18, 27-30]. Furthermore, the results from animal experiments and human kidney biopsies demonstrating activation of the mTOR pathway during active nephritis, and the therapeutic effect of mTOR inhibitor in murine lupus, provide a strong rationale for testing the effect of mTOR inhibitors in the treatment of human LN $[16,17]$. In this regard, previous studies have shown that mTOR activity was increased in lupus T cells, and rapamycin treatment reversed TCRzeta deficiency and FcepsilonR1gamma upregulation, which underlied aberrant $\mathrm{T}$ cell activation and death pathway selection in SLE [31]. One limitation of our study was that we did not investigate the effect of treatment on mTOR activity in the T cells of our LN patients.

In this study, all patients received sirolimus treatment either because of intolerance to standard immunosuppressants or a history of malignancy. In the former group, the side-effects due to their previous immunosuppressants resolved in all except one patient after conversion to sirolimus. In the latter group, there was no tumor recurrence after a follow-up of $54.0 \pm 16.9$ months. 
Table 2: Treatment details and outcomes of 16 lupus nephritis patients who received sirolimus during active nephritis or disease quiescence

\begin{tabular}{|c|c|c|c|c|c|c|}
\hline & $\begin{array}{l}\text { Indication of } \\
\text { treatment }\end{array}$ & $\begin{array}{l}\text { Duration } \\
\quad \text { of } \\
\text { treatment }\end{array}$ & $\begin{array}{l}\text { Dose of } \\
\text { concomitant } \\
\text { Prednisolone }\end{array}$ & $\begin{array}{l}\text { Mean } \\
\text { Achieved } \\
\text { Sirolimus } \\
\text { Dosage }\end{array}$ & $\begin{array}{l}\text { Mean 12-hr } \\
\text { trough } \\
\text { sirolimus } \\
\text { level }(\mu \mathrm{g} / \mathrm{L})\end{array}$ & Key Outcomes \\
\hline \multicolumn{7}{|c|}{ Patients who received sirolimus during active nephritis } \\
\hline Patient 1 & History of malignancy & 8 weeks & $35 \mathrm{mg} / \mathrm{D}$ & $1 \mathrm{mg} / \mathrm{D}$ & $2.9 \pm 0.1$ & $\begin{array}{l}\text { Treatment discontinuation due to skin rash; one } \\
\text { episode of hematological flare; no recurrence of } \\
\text { malignancy }\end{array}$ \\
\hline Patient 2 & MMF intolerance & 84 months & $40 \mathrm{mg} / \mathrm{D}$ & $1 \mathrm{mg} / \mathrm{D}$ & $6.1 \pm 3.2$ & Achieved CR; no clinical relapse \\
\hline Patient 3 & History of malignancy & 82 months & $50 \mathrm{mg} / \mathrm{D}$ & $2 \mathrm{mg} / \mathrm{D}$ & $6.0 \pm 2.5$ & $\begin{array}{l}\text { Achieved CR; no clinical relapse or recurrence of } \\
\text { malignancy }\end{array}$ \\
\hline Patient 4 & MMF intolerance & 10 weeks & $40 \mathrm{mg} / \mathrm{D}$ & $1 \mathrm{mg} / \mathrm{D}$ & $7.7 \pm 0.6$ & $\begin{array}{l}\text { Treatment discontinuation due to cholecystitis; ESRF } \\
\text { after } 27 \text { months }\end{array}$ \\
\hline Patient 5 & FK intolerance & 84 months & $40 \mathrm{mg} / \mathrm{D}$ & $3 \mathrm{mg} / \mathrm{D}$ & $5.9 \pm 1.3$ & Achieved CR; no clinical relapse \\
\hline \multicolumn{7}{|c|}{ Patients who received sirolimus during disease quiescence } \\
\hline Patient 6 & MMF intolerance & $\begin{array}{c}110 \\
\text { months }\end{array}$ & $5 \mathrm{mg} / \mathrm{D}$ & $1 \mathrm{mg} / \mathrm{D}$ & $3.9 \pm 0.4$ & No clinical relapse \\
\hline Patient 7 & MMF intolerance & 11 weeks & $5 \mathrm{mg} / \mathrm{D}$ & $1 \mathrm{mg} / \mathrm{D}$ & $3.7 \pm 0.1$ & Treatment discontinuation due to headache \\
\hline Patient 8 & History of malignancy & 65 months & $4 \mathrm{mg} / \mathrm{D}$ & $1 \mathrm{mg} / \mathrm{D}$ & $3.5 \pm 0.6$ & No clinical relapse or recurrence of malignancy \\
\hline Patient 9 & FK intolerance & 11 weeks & $5 \mathrm{mg} / \mathrm{D}$ & $1 \mathrm{mg} / \mathrm{D}$ & $<2.0$ & Treatment discontinuation due to skin rash \\
\hline Patient 10 & History of malignancy & 48 months & $5 \mathrm{mg} / \mathrm{D}$ & $2 \mathrm{mg} / \mathrm{D}$ & $3.8 \pm 0.8$ & No clinical relapse or recurrence of malignancy \\
\hline Patient 11 & MMF intolerance & 56 months & $7.5 \mathrm{mg} / \mathrm{D}$ & $1 \mathrm{mg} / \mathrm{D}$ & $3.7 \pm 2.0$ & No clinical relapse \\
\hline Patient 12 & FK intolerance & 48 months & $6 \mathrm{mg} / \mathrm{D}$ & $1 \mathrm{mg} / \mathrm{D}$ & $3.3 \pm 0.4$ & No clinical relapse \\
\hline Patient 13 & History of malignancy & 48 months & $2.5 \mathrm{mg} / \mathrm{D}$ & $1 \mathrm{mg} / \mathrm{D}$ & $3.9 \pm 0.3$ & No clinical relapse or recurrence of malignancy \\
\hline Patient 14 & History of malignancy & 48 months & $5 \mathrm{mg} / \mathrm{D}$ & $2 \mathrm{mg} / \mathrm{D}$ & $4.8 \pm 0.8$ & No clinical relapse or recurrence of malignancy \\
\hline Patient 15 & History of malignancy & 48 months & $5 \mathrm{mg} / \mathrm{D}$ & $1 \mathrm{mg} / \mathrm{D}$ & $6.4 \pm 1.1$ & No clinical relapse or recurrence of malignancy \\
\hline Patient 16 & MMF intolerance & 36 months & $9 \mathrm{mg} / \mathrm{QD}$ & $1 \mathrm{mg} / \mathrm{D}$ & $2.6 \pm 0.8$ & $\begin{array}{l}\text { One episode of renal relapse; treatment discontinuation } \\
\text { due to leucopenia }\end{array}$ \\
\hline
\end{tabular}

$\mathrm{CR}=$ complete remission; $\mathrm{ESRF}=$ end stage renal failure; $\mathrm{FK}=$ tacrolimus; $\mathrm{MMF}=$ mycophenolate mofetil.

Table 3: Adverse events experienced by 16 lupus nephritis patients who had received prednisolone and sirolimus treatment

\begin{tabular}{lc}
\hline Adverse events & Incidence \\
\hline New onset or worsening of hyperlipidemia & $4(25 \%)$ \\
Hematological abnormalities & $3(18.8 \%)$ \\
$\quad$ Leucopenia & $2(12.5 \%)$ \\
Pancytopenia & $1(6.2 \%)$ \\
Infection & $3(18.8 \%)$ \\
$\quad$ Acute cholecystitis & $1(6.2 \%)$ \\
$\quad$ Urinary Tract infection & $1(6.2 \%)$ \\
$\quad$ Herpes zoster infection & $1(6.2 \%)$ \\
Aphthous ulcer & $2(12.5 \%)$ \\
Skin rash & $2(12.5 \%)$ \\
Headache & $1(6.2 \%)$ \\
\hline
\end{tabular}


In this regard, increased long-term risk of malignancy had been reported in LN patients and was associated with excessive mortality $[1,32,33]$. Data from organ transplant recipients shows that long-term immunosuppressive regimens that include mTOR inhibitors are associated with reduced overall cancer risk when compared to patients not treated with mTOR inhibitors, and the difference is due to a lower incidence of non-melanoma skin cancers and kidney cancers $[13,34,35]$. Also, sirolimus treatment has been associated with complete remission of Kaposi sarcoma and significant reduction in the risk of recurrent non-melanocytic skin cancers $[13,34]$. In this context, sirolimus presents an attractive option for $\mathrm{LN}$ patients who required prolonged maintenance immunosuppression and had a history of neoplastic disease.

The use of sirolimus as continuous inductionmaintenance treatment is still exploratory due to the small number of patients. Two patients required discontinuation of sirolimus because of the occurrence of acute cholecystitis and leucopenia respectively. The relationship of sirolimus with these adverse events is unclear since the patient who developed cholecystitis had pre-existing gallstones and the other patient also had leucopenia before commencement of sirolimus. The other patients who tolerated prednisolone and sirolimus induction all showed significant improvements in proteinuria and serological parameters, and such clinical responses were sustained over 36 months. These pilot results suggested that investigation on the use of sirolimus induction would be worthwhile in future clinical studies.

Side-effects of sirolimus include dyslipidemia, oral ulcers, myelosuppression, impaired wound healing and rarely interstitial pneumonitis $[26,36]$. Oral ulceration may be severe enough to require drug discontinuation. This did not occur in our patients probably because the avoidance of high trough blood levels and prior advice on oral hygiene and the use of mouth gargle. These long-term results, albeit in a relatively small number of patients, suggest that sirolimus treatment is relatively well tolerated in LN patients. Deterioration of lipid profile was the most frequently observed adverse event in this cohort, but all cases were adequately controlled with statins. Myelosuppression occurred in three patients. While the patients with pancytopenia also had acute cholecystitis, the other two episodes of leucopenia were not associated with infective complications.

\section{MATERIALS AND METHODS}

The case records of LN patients who attended the SLE Clinic at Queen Mary Hospital during the period of January 2007 to Jan 2016 were reviewed. The study was approved by the University of Hong Kong/Hong Kong Hospital Authority Wester Cluster Institution Review Board (Approval number: UW11-115). Patients with Class $\mathrm{III} \pm \mathrm{V}$ or IV $\pm \mathrm{V}$ or pure Class V LN (defined according to the ISN-RPS 2003 classification) who had been treated with sirolimus were included in this retrospective study. In our center, the first-line treatment for proliferative $\mathrm{LN}$ (i.e. Class III $\pm \mathrm{V}$ or IV $\pm \mathrm{V} \mathrm{LN}$ ) was prednisolone combined with MMF for induction followed by low-dose prednisolone plus either MMF or AZA as maintenance immunosuppression $[8,11,12]$. Cyclophosphamide was reserved for patients with severe crescentic features in the kidney biopsy. Calcineurin inhibitors (CNI) were used as second-line treatment in patients who could not tolerate MMF, or as add-on therapy in patients who showed persistent significant proteinuria $(>2 \mathrm{~g} / \mathrm{D})$ despite standard therapy for 6 months [37]. Sirolimus was used in patients who could not tolerate standard immunosuppressants or who had a history of malignancy. During the induction phase, oral prednisolone was commenced at $0.8 \mathrm{mg} / \mathrm{kg} / \mathrm{D}$ and tapered by $5 \mathrm{mg} / \mathrm{D}$ every fortnight, to a maintenance dose of $5-7.5 \mathrm{mg} / \mathrm{D}$ at approximately 5 months. Sirolimus, when used during active nephritis, was commenced at 5 $\mathrm{mg}$ on the first day and followed by $2 \mathrm{mg} / \mathrm{D}$. The sirolimus dose was adjusted to aim for target trough blood levels of 6-8 $\mu \mathrm{g} / \mathrm{L}$. When used as maintenance immunosuppression in patients with quiescent disease, sirolimus was initiated at $1 \mathrm{mg} / \mathrm{D}$ and titrated to achieve a trough level of 4-6 $\mu \mathrm{g} / \mathrm{L}$. The initial dosages of sirolimus were reduced by half in patients who also received concomitant diltiazem treatment. Patients were followed at 2 weeks, 4 weeks and then every 12 weeks. During each clinic visit, complete blood counts, liver and renal functions, anti-dsDNA, serum C3/4, 12-hr trough sirolimus levels and urinary protein were monitored. Any clinically significant events and side effects were documented. Lipid (total cholesterol, triglyceride and LDL levels) and glycemic (fasting glucose and HBA1c) profiles were measured at 6 months' interval.

\section{Statistical analysis}

Continuous variables are expressed as mean (SD) or median (range), and analysed by Student's $t$-test or Mann-Whitney test where appropriate. Categorical variables were expressed as frequencies (percentages) and analysed by Chi-square test or Fisher-Exact test where appropriate. All statistical analyses were performed using SAS statistical software version 9.1 (SAS Institute Inc., Cary, NC) and $p$-value $<0.05$ were considered statistically significant.

\section{CONCLUSIONS}

The preliminary results suggest that sirolimus combined with prednisolone appears effective and relatively well tolerated in patients with $\mathrm{LN}$, and could be considered a possible alternative treatment for active or quiescent LN, especially in patients who have a history of malignancy or who cannot tolerate standard immunosuppressive medications. 


\section{Abbreviations}

$\mathrm{AZA}=$ azathioprine; $\mathrm{CNI}=$ calcineurin inhibitors; $\mathrm{CYC}=$ cyclophosphamide LN = lupus nephritis; $\mathrm{MMF}$ $=$ mycophenolate mofetil; $\mathrm{mTOR}=$ mammalian target of rapamycin; $\mathrm{SLE}=$ systemic lupus erythematosus .

\section{Author contributions}

Desmond Y. H. YAP, Chan TM: Conception of study, patient care, analysis of data and preparation of manuscript; Colin Tang: analysis of data; Gary C. W. Chan Lorraine P. Y. Kwan, Maggie K. M. Ma, Maggie M. Y. Mok: care of patients and preparation of manuscript.

\section{ACKNOWLEDGMENTS}

None.

\section{CONFLICTS OF INTEREST}

The authors have no conflicts of interest or financial disclosure to declare.

\section{FUNDING}

This study did not receive any funding or financial support.

\section{REFERENCES}

1. Yap DY, Tang CS, Ma MK, Lam MF, Chan TM. Survival analysis and causes of mortality in patients with lupus nephritis. Nephrol Dial Transplant. 2012; 27:3248-54.

2. Saxena R, Mahajan T, Mohan C. Lupus nephritis: current update. Arthritis Res Ther. 2011; 13:240.

3. Jakes RW, Bae SC, Louthrenoo W, Mok CC, Navarra SV, Kwon N. Systematic review of the epidemiology of systemic lupus erythematosus in the Asia-Pacific region: prevalence, incidence, clinical features, and mortality. Arthritis Care Res (Hoboken). 2012; 64:159-68.

4. Hahn BH, McMahon MA, Wilkinson A, Wallace WD, Daikh DI, Fitzgerald JD, Karpouzas GA, Merrill JT, Wallace DJ, Yazdany J, Ramsey-Goldman R, Singh K, Khalighi M, et al, and American College of Rheumatology. American College of Rheumatology guidelines for screening, treatment, and management of lupus nephritis. Arthritis Care Res (Hoboken). 2012; 64:797-808.

5. Bertsias GK, Tektonidou M, Amoura Z, Aringer M, Bajema I, Berden JH, Boletis J, Cervera R, Dörner T, Doria A, Ferrario F, Floege J, Houssiau FA, et al, and European League Against Rheumatism and European Renal Association-European Dialysis and Transplant Association. Joint European League Against Rheumatism and European Renal Association-European Dialysis and Transplant
Association (EULAR/ERA-EDTA) recommendations for the management of adult and paediatric lupus nephritis. Ann Rheum Dis. 2012; 71:1771-82.

6. Cattran DC, Feehally J, Cook HT, Liu ZH, Fervenza FC, Mezzano SA, Floege J, Nachman PH, Gipson DS, Praga M, Glassock RJ, JRadhakrishnan J, Hodson EM, et al. Kidney Disease: Improving Global Outcomes (KDIGO) Glomerulonephritis Work Group. KDIGO Clinical Practice Guidelines for Glomerulonephritis. Kidney Int Suppl. 2012; 2:139-274.

7. Mok CC, Yap DY, Navarra SV, Liu ZH, Zhao MH, Lu L, Takeuchi T, Avihingsanon Y, Yu XQ, Lapid EA, LugueLizardo LR, Sumethkul V, Shen N, et al, and Asian Lupus Nephritis Network (ALNN). Overview of lupus nephritis management guidelines and perspective from Asia. Nephrology (Carlton). 2014; 19:11-20.

8. Chan TM, Tse KC, Tang CS, Mok MY, Li FK, and Hong Kong Nephrology Study Group. Long-term study of mycophenolate mofetil as continuous induction and maintenance treatment for diffuse proliferative lupus nephritis. J Am Soc Nephrol. 2005; 16:1076-84.

9. Austin HA 3rd, Illei GG, Braun MJ, Balow JE. Randomized, controlled trial of prednisone, cyclophosphamide, and cyclosporine in lupus membranous nephropathy. J Am Soc Nephrol. 2009; 20:901-11.

10. Illei GG, Austin HA 3rd, Crane M, Collins L, Gourley $\mathrm{MF}$, Yarboro $\mathrm{CH}$, Vaughan EM, Kuroiwa T, Danning CL, Steinberg AD, Klippel JH, Balow JE, Boumpas DT. Combination therapy with pulse cyclophosphamide plus pulse methylprednisolone improves long-term renal outcome without adding toxicity in patients with lupus nephritis. Ann Intern Med. 2001; 135:248-57.

11. Chan TM, Li FK, Tang CS, Wong RW, Fang GX, Ji YL, Lau CS, Wong AK, Tong MK, Chan KW, Lai KN, and Hong Kong-Guangzhou Nephrology Study Group. Efficacy of mycophenolate mofetil in patients with diffuse proliferative lupus nephritis. N Engl J Med. 2000; 343:1156-62.

12. Yap DY, Ma MK, Mok MM, Tang CS, Chan TM. Longterm data on corticosteroids and mycophenolate mofetil treatment in lupus nephritis. Rheumatology (Oxford). 2013; 52:480-86.

13. Fantus D, Rogers NM, Grahammer F, Huber TB, Thomson AW. Roles of mTOR complexes in the kidney: implications for renal disease and transplantation. Nat Rev Nephrol. 2016; 12:587-609.

14. Ekberg H, Tedesco-Silva H, Demirbas A, Vítko S, Nashan B, Gürkan A, Margreiter R, Hugo C, Grinyó JM, Frei U, Vanrenterghem Y, Daloze P, Halloran PF, and ELITESymphony Study. Reduced exposure to calcineurin inhibitors in renal transplantation. N Engl J Med. 2007; 357:2562-75.

15. Schena FP, Pascoe MD, Alberu J, del Carmen Rial M, Oberbauer R, Brennan DC, Campistol JM, Racusen L, Polinsky MS, Goldberg-Alberts R, Li H, Scarola J, Neylan JF, and Sirolimus CONVERT Trial Study Group. 
Conversion from calcineurin inhibitors to sirolimus maintenance therapy in renal allograft recipients: 24-month efficacy and safety results from the CONVERT trial. Transplantation. 2009; 87:233-42.

16. Lui SL, Yung S, Tsang R, Zhang F, Chan KW, Tam S, Chan TM. Rapamycin prevents the development of nephritis in lupus-prone NZB/W F1 mice. Lupus. 2008; 17:305-13.

17. Lui SL, Tsang R, Chan KW, Zhang F, Tam S, Yung S, Chan TM. Rapamycin attenuates the severity of established nephritis in lupus-prone NZB/W F1 mice. Nephrol Dial Transplant. 2008; 23:2768-76.

18. Alperovich G, Rama I, Lloberas N, Franquesa M, Poveda R, Gomà M, Herrero-Fresneda I, Cruzado JM, Bolaños N, Carrera M, Grinyó JM, Torras J. New immunosuppresor strategies in the treatment of murine lupus nephritis. Lupus. 2007; 16:18-24.

19. Warner LM, Adams LM, Sehgal SN. Rapamycin prolongs survival and arrests pathophysiologic changes in murine systemic lupus erythematosus. Arthritis Rheum. 1994; 37:289-97.

20. Fernandez D, Bonilla E, Mirza N, Niland B, Perl A. Rapamycin reduces disease activity and normalizes $\mathrm{T}$ cell activation-induced calcium fluxing in patients with systemic lupus erythematosus. Arthritis Rheum. 2006; 54:2983-88.

21. Yap DY, Ma MK, Tang CS, Chan TM. Proliferation signal inhibitors in the treatment of lupus nephritis: preliminary experience. Nephrology (Carlton). 2012; 17:676-80.

22. Podder H, Stepkowski SM, Napoli K, Kahan BD. Pharmacokinetic interactions between sirolimus and cyclosporine exacerbate renal dysfunction. Transplant Proc. 2001; 33:1086.

23. Stylianou K, Petrakis I, Mavroeidi V, Stratakis S, Kokologiannakis G, Lioudaki E, Liotsi C, Kroustalakis N, Vardaki E, Stratigis S, Perakis K, Kyriazis J, Nakopoulou $\mathrm{L}$, et al. Rapamycin induced ultrastructural and molecular alterations in glomerular podocytes in healthy mice. Nephrol Dial Transplant. 2012; 27:3141-48.

24. Diekmann F, Andrés A, Oppenheimer F. mTOR inhibitorassociated proteinuria in kidney transplant recipients. Transplant Rev (Orlando). 2012; 26:27-29.

25. Ponticelli C, Graziani G. Proteinuria after kidney transplantation. Transpl Int. 2012; 25:909-17.

26. Morath C, Arns W, Schwenger V, Mehrabi A, Fonouni H, Schmidt J, Zeier M. Sirolimus in renal transplantation. Nephrol Dial Transplant. 2007(Suppl 8); 22:viii61-viii65.

27. Stylianou K, Petrakis I, Mavroeidi V, Stratakis S, Vardaki E, Perakis K, Stratigis S, Passam A, Papadogiorgaki E, Giannakakis K, Nakopoulou L, Daphnis E. The PI3K/Akt/
mTOR pathway is activated in murine lupus nephritis and downregulated by rapamycin. Nephrol Dial Transplant. 2011; 26:498-508.

28. Gu Z, Tan W, Ji J, Feng G, Meng Y, Da Z, Guo G, Xia Y, Zhu X, Shi G, Cheng C. Rapamycin reverses the senescent phenotype and improves immunoregulation of mesenchymal stem cells from MRL/lpr mice and systemic lupus erythematosus patients through inhibition of the mTOR signaling pathway. Aging (Albany NY). 2016; 8:1102-14. https://doi.org/10.18632/aging.100925.

29. Lai ZW, Borsuk R, Shadakshari A, Yu J, Dawood M, Garcia R, Francis L, Tily H, Bartos A, Faraone SV, Phillips P, Perl A. Mechanistic target of rapamycin activation triggers IL-4 production and necrotic death of double-negative $\mathrm{T}$ cells in patients with systemic lupus erythematosus. J Immunol. 2013; 191:2236-46.

30. Kato H, Perl A. Mechanistic target of rapamycin complex 1 expands Th17 and IL-4+ CD4-CD8- double-negative $\mathrm{T}$ cells and contracts regulatory $\mathrm{T}$ cells in systemic lupus erythematosus. J Immunol. 2014; 192:4134-44.

31. Fernandez DR, Telarico T, Bonilla E, Li Q, Banerjee S, Middleton FA, Phillips PE, Crow MK, Oess S, MullerEsterl W, Perl A. Activation of mammalian target of rapamycin controls the loss of TCRzeta in lupus $\mathrm{T}$ cells through HRES-1/Rab4-regulated lysosomal degradation. J Immunol. 2009; 182:2063-73.

32. Bernatsky S, Boivin JF, Joseph L, Rajan R, Zoma A, Manzi S, Ginzler E, Urowitz M, Gladman D, Fortin PR, Petri M, Edworthy S, Barr S, et al. An international cohort study of cancer in systemic lupus erythematosus. Arthritis Rheum. 2005; 52:1481-90.

33. Bernatsky S, Joseph L, Boivin JF, Gordon C, Urowitz M, Gladman D, Fortin PR, Ginzler E, Bae SC, Barr S, Edworthy S, Isenberg D, Rahman A, et al. The relationship between cancer and medication exposures in systemic lupus erythaematosus: a case-cohort study. Ann Rheum Dis. 2008; 67:74-79.

34. Yanik EL, Siddiqui K, Engels EA. Sirolimus effects on cancer incidence after kidney transplantation: a metaanalysis. Cancer Med. 2015; 4:1448-59.

35. Yanik EL, Gustafson SK, Kasiske BL, Israni AK, Snyder JJ, Hess GP, Engels EA, Segev DL. Sirolimus use and cancer incidence among US kidney transplant recipients. Am J Transplant. 2015; 15:129-36.

36. Merkel S, Mogilevskaja N, Mengel M, Haller H, Schwarz A. Side effects of sirolimus. Transplant Proc. 2006; 38:714-15.

37. Yap DY, Ma MK, Mok MM, Kwan LP, Chan GC, Chan TM. Long-term data on tacrolimus treatment in lupus nephritis. Rheumatology (Oxford). 2014; 53:2232-37. 